\title{
UNDERSTANDING THE FACTORS INFLUENCING BANKING CUSTOMERS' FINANCIAL ASSET OWNERSHIP
}

\author{
Aimatul Yumna ${ }^{1}$ and Joan Marta ${ }^{2}$ \\ ${ }^{1}$ Management Department/Universitas Negeri Padang, Indonesia, aimatulyumna@gmail.com \\ ${ }^{2}$ Economics Department/Universitas Negeri Padang, Indonesia, jomarta01@gmail.com
}

\begin{abstract}
The objective of this study is to evaluate the factors which influence banking customers' financial asset ownership. Using the pyramid of Maslahah framework, the study classifies the needs of banking customers into four levels: those for basic financial services (haijiyat); for financial assets for security or as a precaution (darruriyat); for financial assets for investment (tahsiniyah); and those for financial assets for religious purposes. To answer the research questions, a binomial logistic model was applied and the primary data were collected using a questionnaire survey with 300 respondents in Indonesia. It was found that the pattern of ownership of financial assets follows the order proposed in the theory of the pyramid of Maslahah. The study also found that financial asset ownership for transaction needs was mainly influenced by the variables of income and credit and that ownership of such assets for security or precautionary needs was largely determined by life cycle variables. In addition, ownership for investment needs was strongly influenced by the level of education, and for religious needs it was mainly determined by income levels and life cycle variables. The study findings provide important information for mapping the financial needs of Islamic banking customers.
\end{abstract}

Keywords: Islamic banking, Saving, Life cycle model, Financial needs. JEL classification: D14; G21; G51.

Article history:

Received : October 14, 2021

Revised : January 15, 2021

Accepted : February 8, 2021

Available online : February 28, 2021

https://doi.org/10.21098/jimf.v7i1.1330 


\section{INTRODUCTION}

\subsection{Background}

Individual asset ownership consists of both financial and non-financial assets, with ownership determined by the different financial needs of individuals. According to the pyramid of Maslahah, financial needs can be classified into three levels, namely basic financial needs, emergency financial needs and financial needs for asset growth (Ahmed, 2011b). Individuals will use various types of financial and non-financial assets to meet their various financial needs.

Previous research on the factors influencing asset ownership has proposed that the distribution of asset ownership is based on different levels of income and welfare (Xiao, 1996; Xiao \& Anderson, 1997). Individuals with different income levels will have different types of assets in varying proportions. Those with limited income will choose a financial asset that is only used for transaction purposes, namely one that has high liquidity and low risk. They will start to consider having riskier and higher return assets in line with increasing income. In addition to income, the patterns of asset ownership can be explained using life cycle theory. This theory explains that asset ownership is influenced by a person's life cycle; variables such as age, marital status and children have a significant influence on such ownership. The theory also posits that individuals with different life cycles will have various types of assets, which are used for different purposes (Bodie et al ., 2007).

Study of the patterns of ownership of financial assets based on the life cycle theory will provide important information for financial planners, bankers and related financial authorities in understanding the financial needs of potential customers in order to meet these.

\subsection{Research Objectives}

The main objective of the study is to understand the patterns and factors influencing financial asset ownership, specifically those of banking customers in Indonesia. As mentioned by Ahmed (2011b), understanding the factors that affect customers' asset ownership is very important for banking in its development of consumeroriented products. By extending the pyramid of Maslahah, the study evaluates the factors that influence banking customers' ownership of various types of financial assets that are used to meet basic financial needs, as well as security, investment and religious needs. Specifically, the objectives of this study are as follows:

1. To examine the factors influencing banking customers' financial asset ownership.

2. To map banking customer financial needs based on the pyramid of Maslahah framework.

The paper is organized as follows. First, after discussing the motivation for the study and the research objectives in the section 1 , the related literature on the pyramid of Maslahah, life cycle theory and asset ownership is reviewed in section 2 . In section 3 , the paper discusses the model development and research method employed to answer the research question . Further, in section 4, the findings of the study are discussed, while in section 5 and important conclusions are drawn and recommendations made. 


\section{LITERATURE REVIEW}

\subsection{Background Theory}

Ahmed (2011), in his book Product Development in Islamic Bank, explains that the main objective of product development in Islamic banking is to realise Maqasid $\mathrm{Al}$ Shariah, which enables the creation of growth and justice. Product development in Islamic banking must follow two main provisions, namely compliance with sharia and realising the social goals of financial institutions to provide comprehensive financial services for all people, including the poor. Furthermore, to be able to compete in the industry, Islamic banking product development must pay attention to the needs and desires of its customers. The needs of clients can be explained using the pyramid of Maslahah approach (Ahmed, 2011a; Aris et al., 2013). This theory contends that Islamic banking should be able to meet three consumer needs, namely those of necessity/essentiality (daruriyat), of complementary requirements (hajiyyat) and of beautifications or embellishments (tahsiniyat).

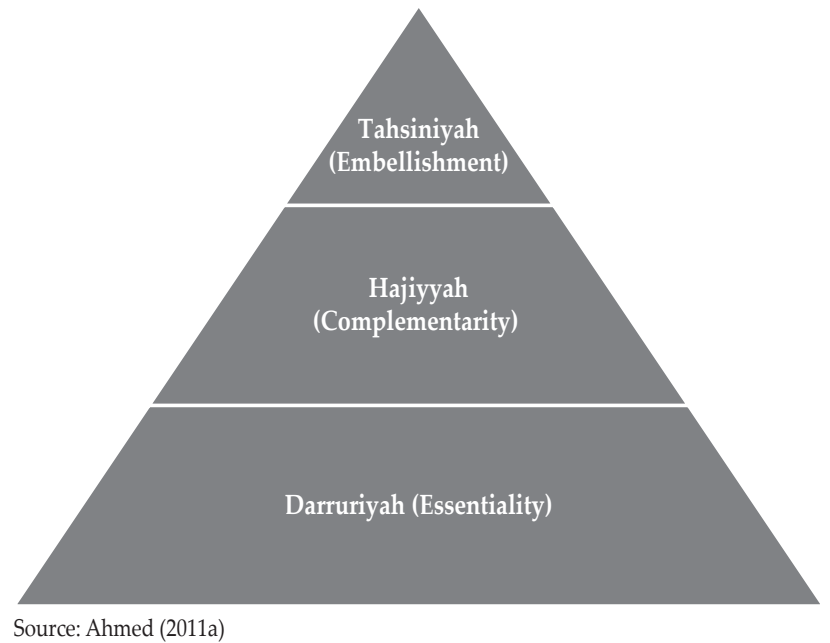

Figure 1 .

The Pyramid of Maslahah

The pyramid of Maslahah explains that there are three levels of human needs that must be met. At the bottom level, darruriyah refers to the basic needs for all humans to survive. Currently, in the era of distruptive technology, it is necessary for Islamic banking to be able to provide basic financial products that are easily accessible, flexible and inexpensive After the basic needs are met, people will have a need for security. This security requirement is a complementary requirement (hajiyat) and is located at the middle level of the pyramid of Maslahah. Financial institutions can fulfil this need for security by providing financial products that can be used to protect and maintain financial stability in the future. Related products include planned deposits, insurance, pension plans, and time deposits, all of which can satisfy the needs for security and protection. Once these needs are fulfilled, people's needs will rise to the next level, namely embellishment/ 
tahsiniyah. At this top level, people have the need to grow and develop, both in terms of assets and as individuals. Developing assets can be achieved through investment activities, which allow assets to grow faster against inflation and taxes. Products in this category include investments in stocks, sukuk/bonds, mutual funds and other investment products. Using the three levels of financial needs, financial institututions must be able to provide three types of financial products, namely:

1. Survival products: demand deposits, savings, and mortgages.

2. Security products: insurance, pension savings, and deposits.

3. Growth products: investment-based banking products to reduce tax and inflation risks.

Households will allocate assets to meet their various financial needs using a variety of financial assets available on the financial market. Several theories explain how people allocate assets, including the life cycle theory of Modigliani and Brumberg (1954) and the bequest theory of Bernheim et al. (1986). Life cycle theory proposes that individuals will maximise their utility and maintain their level of consumption over their life time, assuming they have a stable income throughout their lives. As a consequence, in order to smooth consumption, they will make a greater proportion of their savings during their working periods, and spend more during their retirement. This theory has been widely used as a framework for explaining household asset allocation.

To meet the various financial needs, ownership of financial assets is often influenced by the life cycle variable. Previous studies have found evidence of different types of asset ownership depending on different birth cohorts (Poterba \& Samwick, 1997). In the early phase of the life cycle, households tend to have debt, with financial products related to loans and mortgages being popular among young households. In the intermediate phase, households will start accumulating assets, pay off their debts, and start owning financial products for saving and investment purposes. On the other hand, older households use their reserves to cover daily expenditure. The traditional life cycle model shows a positive correlation between savings and income growth. The level of saving will increase when someone starts working and fall when they marry and have children.

One important motivation for saving is to maintain consumption stability in the event of unexpected contingencies (Cagetti, 2003). People will start saving for retirement only when they are nearing retirement age. Various kinds of financial assets are used to fulfil the precautionary motives, such as insurance, time deposits, and planned savings. Financial assets for such needs are classified as liquid assets, which are easy to convert into cash, but with higher transaction costs compared to current saving accounts.After meeting the precautionary needs, people will start thinking about investment allocation, since insured households will invest more in stocks and bonds compared to uninsured ones (Qiu, 2016). Asset allocation for investment often follows the life cycle pattern; as such, someone's knowledge about investment and risk increases along with age (Peijnenburg, 2018). The proportion of wealth allocated to investment over the life cycle follows a hump shape pattern due to uncertainty aversion; that is, the allocation of assets for investment will peak in the middle of life cycle period and begin to decline people approach retirement age. 
Although life cycle theory is widely used to explain asset allocation, some phenomena, such as an increase in saving among the elderly, cannot be explained by it. Bequest theory is another theory that is often used to explain ownership and allocation of assets. This explains that a people's desire to hand down an inheritance to their descendants is one important factor in the allocation of assets. Empirical studies have found that this bequest motive can explain the allocation of household assets in various countries such as America and China in order to meet the need for greater medical treatment costs (Ameriks et al., 2011).

\subsection{Previous Studies}

Previous research on the factors influencing financial asset ownership has discussed the fact that individuals with different income levels will have different types of assets in varying proportions. In addition, asset ownership is significantly influenced by life cycle variables. The use of the life cycle model to explain the ownership of financial assets has identified a different pattern of financial asset ownership in each life cycle stage (Lansing \& Morgan, 1955). Similarly, Bodie et al. (2007) also state that financial asset ownership involves different decisions made by individual families based on their life cycle. An empirical study conducted by Xiao (1996) shows that life cycle proxy variables such as the age of the head of the family, the number and age of children, and marital status, significantly affect families' financial asset ownership. The study also confirms previous research by Shefrin and Thaler (1988), who found that a person's desire to save will be greatly influenced by the level of their life cycle and their family resources. Most studies have made similar findings regarding the significant influence of life cycle on asset ownership, meaning that individuals with different life cycles will use different types of assets for different purposes. The studies imply that financial institutions must pay attention to the family life cycle when offering savings or investment products to their clients.

In addition to income and life cycle, the pattern of asset ownership is also influenced by other factors such as financial goals (Ramaswami et al., 1992); risk appetite (Hallahan et al., 2004); education (Longobardi \& Pagliuca, 2016); and the possession of credit cards and a home (Xiao, 1996). The level of education also greatly influences a person's decision to own assets. Those with a high level of education and good knowledge about investing will prefer to invest in riskier assets in order to obtain higher returns (Sung \& Hanna, 1996). Conversely, those with limited education will own fewer financial assets for investment.

Apart from education, a person's desire to own various financial assets is also influenced by their financial resources such as credit card and home ownership (Xiao, 1996). People who have a credit card also have the tendency to own various other financial assets because they have the opportunity to use the card to meet their needs. Another variable that affects ownership of financial assets is the type of occupation; Hira (1987) explains that the type of work influences the ownership of riskier assets. 


\subsection{Conceptual Framework}

From the background theory discussed above, previous studies have demonstrated the influence between life cycle, income level, education, credit and type of occupation, with the ownership of various financial assets meeting three types of needs, namely transaction needs, security needs, and investment needs, together with financial assets for religious purposes. The framework is shown in Figure 2.
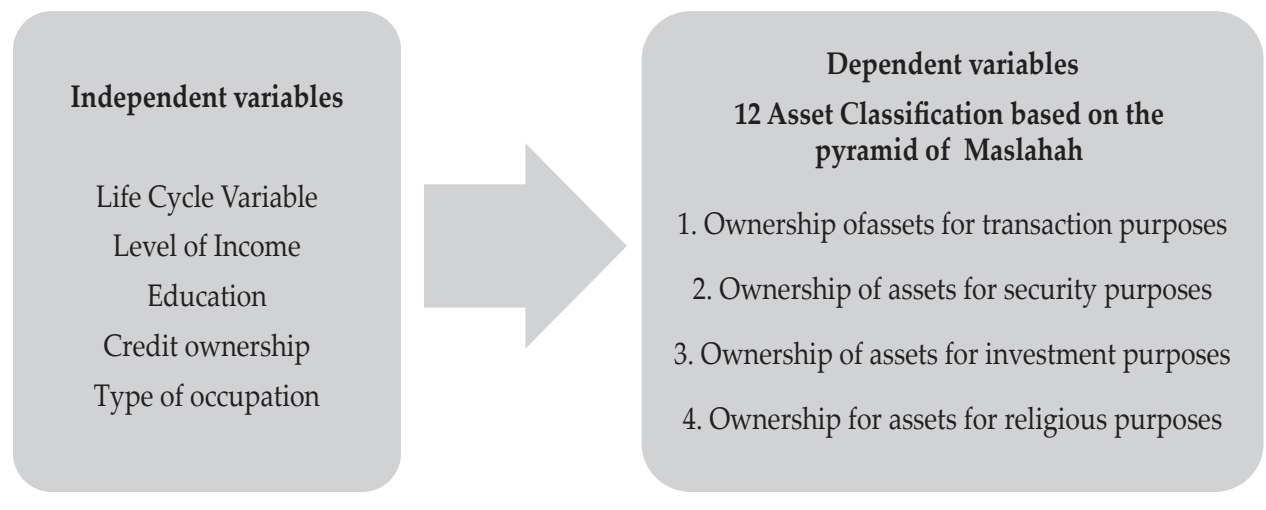

Source: Adapted from Xiao (1996) and Ahmed (2011a)

Figure 2.

Conceptual Framework

\section{METHODOLOGY}

\subsection{Data}

Primary data were collected by conducting a semi-closed questionnaire survey. The study sample comprised banking customers with different age ranges. We employed convenient sampling techniques; in order to find respondents, researchers went to several public places such as cafes, libraries and universities and people were randomly selected to be interviewed after being asked screening questions related to age, income level and bank accounts held. Questionnaire responses were collected from 304 respondents and 300 of these were used for estimation. The respondents included Islamic and conventional banking customers. The survey was conducted in several provincial capital cities in Indonesia, including Jakarta, Surabaya, Yogjakarta, Pekanbaru and Padang.

\subsection{Model Development}

To understand customers' financial needs, the study used the dependent variable related to asset ownership. A person's ownership of a specific asset indicates that there is a financial need to be met in using that asset (Xiao, 1996; Xiao \& Anderson, 1997). For example, someone's education savings indicate that they needs funds to finance education. Ownership of a financial asset is strongly influenced by several factors, including a person's life cycle, income, credit, education level and any mortgage held. 
Using a binomial logit model, this study examined the effect of independent variables relating to life cycle, income, credit, education and occupation of respondents on the ownership of various types of financial assets for transaction, security, investment and religious purposes. The dependent variables used in this study related to ownership of 12 financial and non-financial assets, consisting of (1) assets for transaction needs including savings and current accounts; (2) assets for security and precautionary purposes, including time deposits; (3) planned savings; (4) education savings; (5) assets for investment purposes including mutual funds; (6) unit links ; (7) stocks; (8) bonds/sukuk; (9) property; (10) and gold (11 ); and finally (12), assets for religious purposes, including pilgrimage savings.

The independent variables included life cycle classification and/or life cycle proxy variables. The life cycle proxy variables included age, marital status and number of children in the family. In addition, other explanatory variables were used, including income, credit card ownership, mortgage, education and type of work.

Based on the scale of the variables, the dependent variable used in this study was categorised as dummy variables, given the value of 1 if the customer had a certain financial asset and 0 if otherwise. The independent variables consisted of categorical and numerical ones. The logistic regression model was applied to analyse the relationship between the dependent and independent variables (King, 2008).

The logistic regression model used was:

$$
\widehat{Y}=P=\frac{\exp \left(\hat{a}+\widehat{b}_{1} X 1+\widehat{b}_{2} X 2+\cdots+\widehat{b}_{n} X n\right)}{1+\exp \left(\widehat{a}_{1}+\widehat{b}_{1} X 1+\widehat{b}_{2} X 2+\cdots+\widehat{b}_{n} X n\right)}
$$

Because $\mathrm{Y}$ is an exponential variable, it must be transformed by multiplying each side by

$$
1+\exp \left(\hat{a}+\hat{b}_{1} X 1+\hat{b}_{2} X 2+\cdots+\hat{b}_{n} X n\right)
$$

Therefore, the logit model used was:

$$
Y=\exp \left(\hat{\mathrm{a}}+\hat{\mathrm{b}}_{1} \mathrm{X} 1+\hat{\mathrm{b}}_{2} \mathrm{X} 2+\cdots+\hat{\mathrm{b}}_{\mathrm{n}} \mathrm{Xn}\right)+e
$$

where

Y : Dependent variable - ownership of 12 types of financial assets

X1 : Income

X2 : Gender in dummy variable

X3 : Length of schooling

X4 : Marital status (single, married with children, married without children, single parent)

X5 : Age category (five categories : $\leq 24$ years; 25 to $\leq 34$ years; 35 to $\leq 44$ years; 45 to $\leq 54$ years; and $\geq 55$ years old)

X6 : Mortagage held (dummy variable)

X7 : Outstanding car financing 
X8 : Credit card ownership

X9 : Type of occupation (formal or informal sector)

\section{RESULTS AND ANALYSIS}

\subsection{Results}

\subsubsection{Characteristics of the Respondents}

The study respondents fell into five age level categories: $\leq 24$ years old; 25 to $\leq$ 34 years old; 35 to $\leq 44$ years old; 45 to $\leq 54$ years old; and $\geq 55$ years old. The proportion of respondents in each age range is almost the same, except for young respondents $\leq 25$ years $(8.3 \%)$ and respondents at retirement age $\geq 55$ years (19 $\%)$. The majority of participants were male (65\%). Regarding marital status, most of the respondents were married (76\%), with $20 \%$ unmarried and $4 \%$ with single parent status They had an average of $1-2$ children (44\%); $27 \%$ had more than three children and $28 \%$ no children. In addition, most of the respondents had a diploma, or a bachelor's or graduate degree $(78 \%)$. In general, those chosen for the study had different life cycles in terms of age, marital status and number of children. Their characteristics are shown in Table 1.

Table 1.

Characteristics of the Respondents

\begin{tabular}{lc}
\hline Variable & Percentage (\%) \\
\hline Gender & \\
Male & 65 \\
Female & 35 \\
Age range & \\
$\leq 24$ years & 8.3 \\
25 to $\leq 34$ years & 25 \\
35 to $\leq 44$ years & 23 \\
45 to $\leq 54$ years & 24.3 \\
$\geq 55$ years old & 19.3 \\
Marital status & \\
Unmarried & 20 \\
Married & 76 \\
Single parent & 4 \\
Number of children & \\
$1-2$ children & 44 \\
$\geq 3$ children & 28.3 \\
No children & 27.7 \\
Education level & \\
Below high school & 4 \\
High school & 17 \\
Diploma, bachelors or graduate & 79 \\
Income (per year ) & \\
$\leq 50,000,000$ & 21 \\
$50,000,000-100,000,000$ & 20 \\
$\geq 100,000,000$ & 59 \\
\hline
\end{tabular}

Source: Survey data 


\subsubsection{Financial Asset Ownership and Conditional Financial Asset Ownership of the Respondents}

Table 2 shows the percentage level of ownership of the 12 financial assets and the conditional ownership if the respondent had other financial assets. Assets for transaction needs were held by almost all the respondents; $93 \%$ had a savings account at a bank, with the remaining $6 \%$ having a current account, whereas the percentage of respondents owning security-based financial assets was mostly lower than that of those owning financial assets for transactions. The survey results show that only around $39 \%$ of the respondents had planned savings, $35 \%$ had education savings and only $22 \%$ had time deposits. In addition, the ownership of investment-based financial assets was the least popular financial aset type. Only fewer than $4 \%$ of the respondents owned bonds and mutual funds, and $8 \%$ chose investments in shares. The most popular financial asset for respondents' investments was unit link, but still only at around $10 \%$. Compared to investment in financial assets, the respondents preferred to invest in real assets; $31.3 \%$ chose investment in property and more than $34 \%$ chose investment in gold.

Table 2 shows the conditional ownership of a financial asset if the respondent had another. Some of the interesting results from the conditional ownership of financial assets show that if someone has a savings account, then the percentage of those having a security-based financial asset is around $20-40 \%$, while the percentage of those having an investment-based financial asset is less than $10 \%$. On the other hand, someone who has a current account has a higher probability of owning assets for security and investment than someone who has a regular savings account.

Another interesting finding was the high probability that individuals will have more than one financial asset for security; for example, $83 \%$ of individuals who have education saving also have education insurance. The respondents were also likely to combine more than one type of insurance product. For example, someone who has education or life insurance has a high probability of having health insurance. Table 2 also shows the pattern of the relationship between ownership of security-based and investment-based assets, which indicates the possibility that someone who has assets for investment also has ones for precautionary needs, in the form of planned saving, time deposits or various types of insurance.

In general, the results of the conditional ownership analysis also support the pyramid of Maslahah theory of Ahmed (2011a). The results show that transaction-based financial assets are owned by almost all respondents, whereas security-based financial assets are owned by only around $30 \%$, and an even lower percentage have investment-based financial assets, at less than 10\%. The study shows that respondents who have investment-based assets have a high probability of owning other financial assets based on security or transactions, but not vice versa. Interestingly, in Indonesia people will start to think about having assets for special needs; in this case, saving for pilgrimages before owning other financial assets. $36 \%$ of the respondents had hajj savings, indicating that ownership of financial assets for such needs was considered relatively important, beyond the needs for investment. A summary of asset ownership patterns is shown in Table 2. 


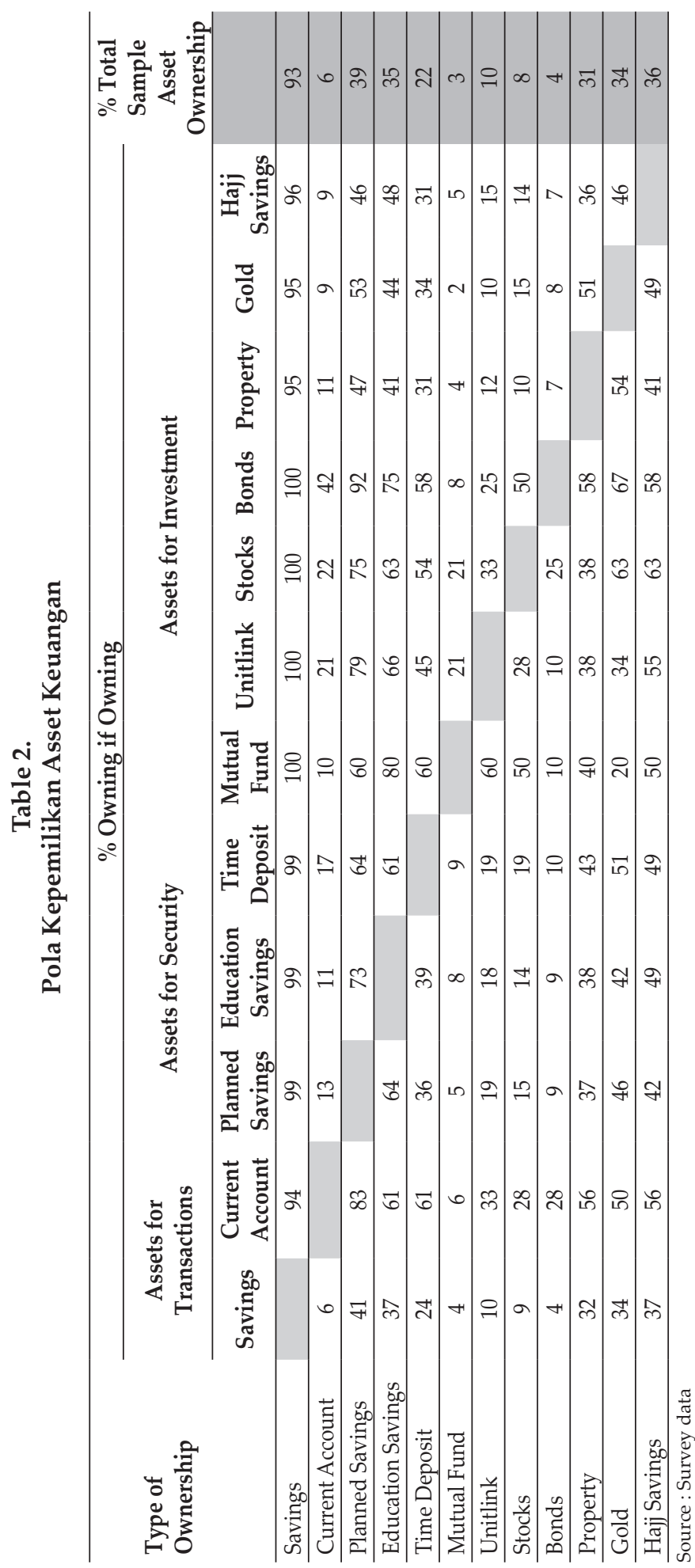




\subsubsection{Logistic Regression Results}

The logistic regression model was used to analyse the factors that affect ownership of the four types of financial assets as indicators of financial needs, namely transaction-based financial assets; financial assets for security and precautionary purposes; financial assets for investment purposes; and financial assets for religious purposes.

\subsubsection{Factors Influencing the Ownership of Financial Assets for Transaction Purposes}

The results of the analysis of the factors that influence the holding of savings are shown in table using 3 . The results shows that such holding is significantly influenced by the type of occupation, credit card ownership, income, and age. Respondents who had jobs in the formal sector had a 2.82 times greater probability of having savings compared to those who worked in the informal sector. The likelihood of someone having savings will increase by 3.07 times if they own credit cards. In addition, when respondents' income increases, their probability of having savings will increase by 1.82 times.

Age category 5 was used as a base variable to make comparisons between the age categories. Compared with respondents aged $\geq 55$ years, the likelihood of someone in age categories 1, 2, and 4 having savings compared with respondents in age category 5 did not differ significantly. However, respondents in the 35 $\leq 44$-year old category were less likely to have savings than those aged over 55 years. This finding disagrees with traditional life cycle theory, which suggests that people will save more in their youth and less in retirement. The results of this study show that banking customers have more savings in retirement compared to the lower age category, because at a younger age customers may allocate more to other types of assets for security or investment purposes.

\subsubsection{Factors Influencing the Ownership of Financial Assets for Security Purposes}

Table 3 shows the findings on the factors influencing financial asset ownership for security purposes, namely planned savings, education savings and time deposits. The results show that the holding of planned savings is influenced by mortgage and credit card ownership, while none of the life cycle variables significantly influences ownership of savings plans. The likelihood of people having a savings plan will increase when they have a mortgage and credit cards. The obligation to pay regular installments makes people maintain financial security by having a savings plan product.

The study has also made some interesting findings regarding the holding of education savings. In addition to being significantly influenced by the level of income and ownership of mortgages, the holding of education savings is greatly influenced by the respondents' marital status. Compared to single respondents, the possibility of married respondents having educational savings increases by 3.63 times and the likelihood of having educational savings products increases by 7.57 times if the respondent is a single parent. 
In contrast to planned and education savings, the ownership of time deposits is significantly influenced by certain life cycle variables, namely age and marital status. Compared with respondents in age category 1 ( $\leq 25$ years), those in the age categories 2, 4 and 5 have more possibility of having deposit products, meaning that the older the respondent, the greater the chance of having such a product. However, the possibility of someone having a deposit product decreases if they are married compared to someone who is unmarried. Those who are married prefer to have education savings. Other significant variables influencing the ownership of time deposits are income level, and the ownership of mortgages and credit cards.

In general, the ownership of banking products for security purposes, especially educational savings and deposits, is strongly influenced by the life cycle variables of age and marital status. The levels of income and credit are also important variables determining the ownership of financial products for security. The holding of a mortgage may indicate financial stability in the banks' eyes. Someone in a fairly stable financial condition will start thinking about having a securitybased financial asset to be used for precautionary purposes.

\subsubsection{Factors Influencing the Ownership of Financial Assets for Investment Purposes}

Table 3 also show the findings on the factors influencing the ownership of financial assets for investment purposes, including ownership of shares, bonds, unit links and mutual funds. The results show that the variables that significantly affect ownership of investment-based financial assets are the respondent's length of study, holding of a mortgage and life cycle variables. As the length of education increases, the likelihood of having shares, bonds, unit links and mutual funds also increases.

In addition, there are several other variables, such as age and life cycle ones, that affect the ownership of stocks and unit links. In terms of share ownership, respondents aged $35-\leq 44$ has a greater likelihood of owning shares compared to those aged $\leq 55$ years. The age variable also clearly explains unit link insurance ownership; i.e., respondents aged $45-\leq 54$ years are eight times more likely than those aged over 55 years to have such insurance.

This study also examines the factors influencing the ownership of real asset investments in property and gold. The tests conducted on the ownership of such investments show that credit card and mortgage ownership are significant variables explaining property and gold ownership. Someone who is a single parent has a greater possibility of having investment property than someone who is not married. Age is another significant variable explaining the ownership of real asset investments; someone who is in age category 4 has a greater chance of owning property compared to those in age category 5. Furthermore, it can also be seen that gender significantly influences the ownership of gold, with the chance of women owning gold higher than that of men.

This finding shows that life cycle variables only affect property ownership and do not affect that of other investment-based financial assets. The important variables determining this type of assets are the level of education and of credit. 


\subsubsection{Factors influencing the ownership of financial assets for religious purposes}

Finally, Table 3 also shows the findings on the factors influencing the ownership of financial assets for religious purposes, namely hajj savings products. The results show that the ownership of such products is influenced by several factors, including income level, gender, status, age and mortgage ownership. The likelihood of someone having hajj savings will increase in line with their income and if they already have somewhere to live. Regarding the age factor, younger respondents (those aged $25-\leq 34$ years) had a lower probability of having hajj savings than those aged over 55. Those who are married also have a greater likelihood of having such savings. The findings of this study can be summarised as follows.

1. Ownership of financial assets for transaction needs is largely determined by the variables of income, credit ownership and type of work. Savings products are not influenced by life cycle variables because such products are needed by all people for their daily transactions.

2. Ownership of financial assets for security or precautionary needs is largely determined by life cycle variables such as age and marital status. Those of a certain age and marital status are likely to have this type of financial asset.

3. Ownership of financial assets for investment needs is strongly influenced by the level of education of the respondents and their economic welfare. Life cycle variables do not influence the decision to own assets for investment needs.

4. Ownership of assets for special needs, namely those of pilgrimages, is mostly influenced by income levels and gender. Several life cycle variables also affect the holding of such savings, including marital status and the age level of the respondents. 


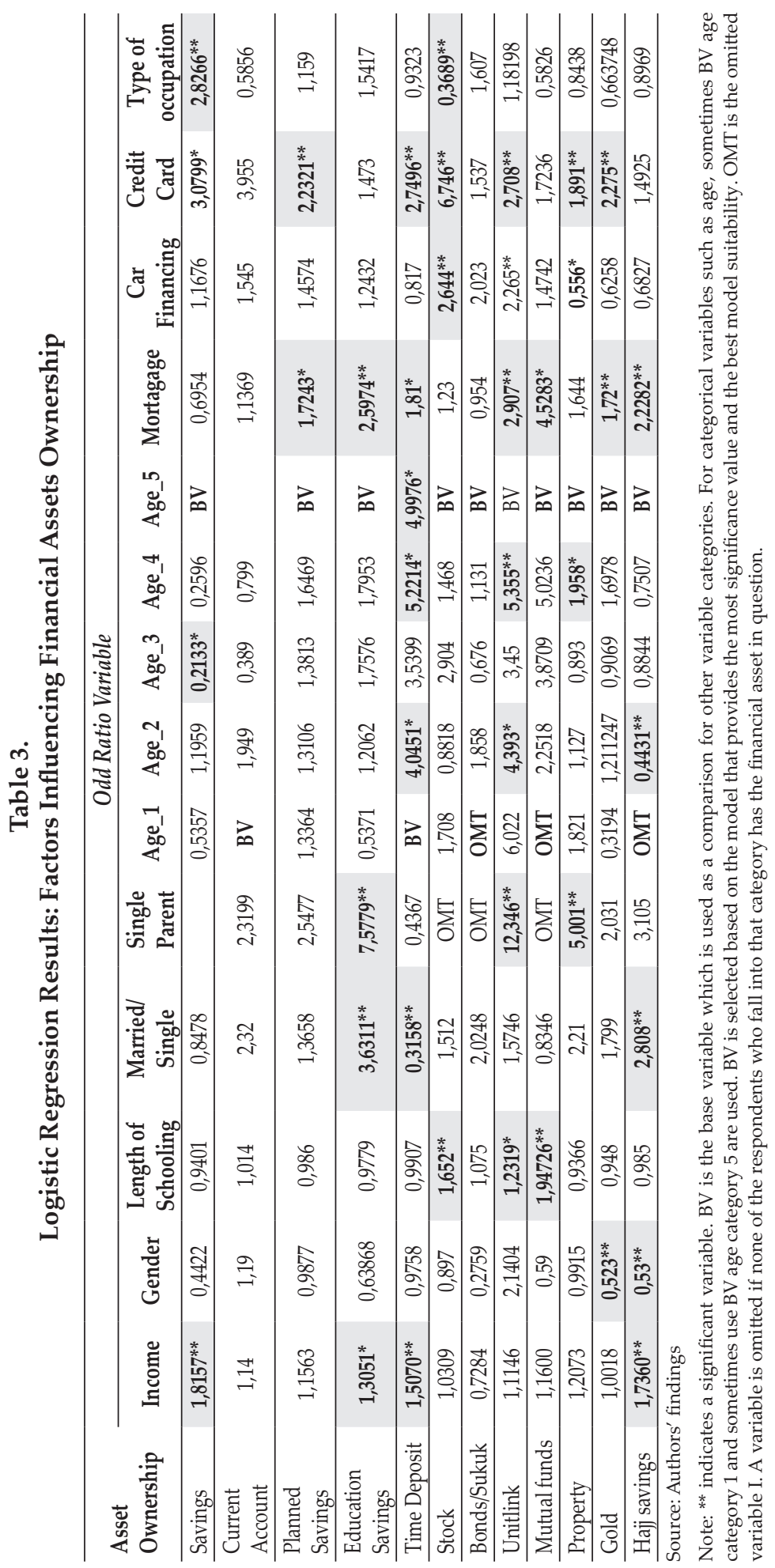




\subsection{Robustness Test}

To check the robustness of the study, a chi-square test was used to examine whether the overall constructed model was significant in predicting the actual cases, and pseudo R-squared to show that the probability of having a specific financial asset can be explained by the explanatory variables. The results of the robustness test are shown in Table 4.

Table 4.

Robustness Test

\begin{tabular}{lccc}
\hline Asset & Chi- Square & Prob & Pseudo R2 \\
\hline Savings & $20,7^{*}$ & 0,0509 & 0,1412 \\
Current Account & 15,09 & 0,2365 & 0,1157 \\
Education Savings & $56,73^{* *}$ & 0,0000 & 0,1476 \\
Planned Savings & $28.56 .00^{* *}$ & 0,0075 & 0,0717 \\
Time Deposit & $28,65^{* *}$ & 0,0073 & 0,0909 \\
Stocks & $48,9^{* *}$ & 0,0000 & 0,2929 \\
Bonds/Sukuk & 8,69 & 0,6509 & 0,0922 \\
Mutual Funds & $22,02^{* *}$ & 0,0242 & 0,2591 \\
Unitlink & $40,97^{* *}$ & 0,0001 & 0,2154 \\
Property & $23,6^{* *}$ & 0,0350 & 0,0638 \\
Gold & $32,36^{* *}$ & 0,0021 & 0,0848 \\
Hajj Savings & $51,55^{* *}$ & 0,0000 & 0,1325 \\
\hline
\end{tabular}

Source: Authors' findings

The chi-square value shows the ability of the overall model to significantly predict the factors that affect ownership of financial assets. The test results show that the chi-square value is significant at $5 \%$ for ten of the financial assets, namely education savings, planned savings, time deposits, stocks, mutual funds, unit link , property investment, gold investment and hajj savings, while it is significant at $10 \%$ for ordinary savings. However, the model as a whole is not significant for current accounts or bonds/sukuk due to the small number of the sample that owned these two assets. Therefore, we can eliminate the findings on current account and bond/sukuk ownership. The pseudo R-square shows the explanatory variables' ability to explain the dependent variable. The test results show that this value is below $20 \%$, indicating that there are many other variables that can explain ownership of financial assets.

\subsection{Analysis}

The results indicate that ownership of the 12 types of financial asset is influenced by different factors. The life cycle variable only affects ownership of assets for security and special purposes. Ownership of security-based financial assets such as education savings and time deposits is significantly influenced by life cycle variables such as marital status and number of children. The results of this study are in accordance with the research of Cagetti (2003), who explains that the motivation to save for precautionary purposes will increase when a person marries and has 
children. Another product, hajj savings, is also influenced by life cycle variables, namely age and marital status (Longobardi \& Pagliuca, 2016; Xiao, 1996)

It was also found that ownership of financial assets for transaction purposes and for investment such as stocks, deposits, and mutual funds is not influenced by life cycle variables. This research indicates that the traditional life cycle theory of Modigliani and Brumberg (1954), which states that someone will save more during their working period in order to smooth their consumption and spend more during the retirement period, cannot be applied to every type of financial asset. Consumers' financial behaviour for investment products is strongly influenced by needs and other factors such as income levels, education levels and level of credit held.

The results of the study indicate that financial investment products are owned by less than $10 \%$ of the respondents; that is, only those who have a high level of education. These results are consistent with research conducted by Sung and Hanna (1996), who found that those with a higher education level had better asset analysis and evaluation skills, and therefore preferred riskier asset types for investment. However, for unit-linked investment products, life cycle variables, in the form of single parent status and age, significantly influence ownership of this type of asset. The unit-linked characteristic, which combines elements of investment and protection, is in demand by single parent respondents, who want more protection for their financial situation. It was also found that certain groups of respondents (those married with children and single parent respondents) used a combination of several financial assets to protect their financial situation. These groups of respondents used extra protection by having several types of financial products for security, including planning savings, education savings and time deposits. A high correlation between ownership of investment-based financial assets and security-based financial assets was found; that is, respondents who already had investment-based assets generally also had security-based assets. This finding confirms the previous study by Qiu (2016), who found that households who owned insurance products would invest more that those who did not. The study findings are also in line with the pyramid of Maslahah, which explains that people will need growth products after their security needs have been met.

Another interesting finding is the significant influence of the credit variable, including home ownership credit, car ownership credit and/or credit card possession, on the ownership of financial assets based on security and investment. This finding indicates that credit ownership information can be used by banks to sell other banking products. Housing loans indicate that a person has met their housing needs, so have more resources to enable them to own other types of financial assets. This confirms the previous study of Xiao (1996), who indicated that families who owned credit cards and a place to live were more likely to have various other financial assets. The findings of this study could be used by the Islamic banking sector to conduct customer mapping, optimise marketing strategies and develop Islamic banking financial products. To map customers' financial needs, this study used the pyramid of Maslahah framework, by dividing financial needs into four types of financial products, comprising basic products, security products, investment products and financial products for religious purposes (Ahmed, 2011a). The results of the study can map consumers in the following way shown in Table 5. 
Table 5.

Customer Mapping

\begin{tabular}{|c|c|c|c|c|}
\hline \multirow{2}{*}{ Product } & \multirow{2}{*}{ Objective } & \multirow{2}{*}{ Type of Product } & \multicolumn{2}{|c|}{ Customer Characteristics } \\
\hline & & & Life Cycle Variable & Other Variables \\
\hline $\begin{array}{l}\text { Darruriyat/ } \\
\text { basic } \\
\text { products. }\end{array}$ & $\begin{array}{l}\text { Providing daily } \\
\text { transaction } \\
\text { needs. } \\
\end{array}$ & $\begin{array}{l}\text { Saving and } \\
\text { current accounts }\end{array}$ & $\begin{array}{l}\text { The entire population } \\
\text { with various life cycles. }\end{array}$ & \\
\hline $\begin{array}{l}\text { Hajiyyat / } \\
\text { security } \\
\text { products. }\end{array}$ & $\begin{array}{l}\text { Products for } \\
\text { security and } \\
\text { protection } \\
\text { purposes. }\end{array}$ & $\begin{array}{l}\text { Planned savings. } \\
\text { Education savings. } \\
\text { Time deposits. }\end{array}$ & $\begin{array}{l}\text { Married customers. } \\
\text { Single parents. }\end{array}$ & $\begin{array}{c}\text { Individuals who have } \\
\text { a mortgage, credit } \\
\text { cards, and a high } \\
\text { income. }\end{array}$ \\
\hline \multirow{2}{*}{$\begin{array}{l}\text { Tahsiniyat } \\
\text { /growth } \\
\text { products for } \\
\text { investment. }\end{array}$} & \multirow{2}{*}{$\begin{array}{l}\text { Products aimed } \\
\text { at asset growth. }\end{array}$} & $\begin{array}{l}\text { Stocks. } \\
\text { Bonds/sukuk. } \\
\text { Mutual funds. }\end{array}$ & $\begin{array}{c}\text { No specific } \\
\text { characteristics. }\end{array}$ & $\begin{array}{l}\text { Individuals who } \\
\text { have a credit card, } \\
\text { housing credit (KPR) } \\
\text { and a high level of } \\
\text { education. }\end{array}$ \\
\hline & & Unitlink & Single parents. & $\begin{array}{c}\text { Individuals who } \\
\text { have a credit card, } \\
\text { housing credit (KPR) } \\
\text { and a high level of } \\
\text { education. }\end{array}$ \\
\hline Hajj savings. & & & $\begin{array}{l}\text { Females in various age } \\
\text { ranges. }\end{array}$ & $\begin{array}{c}\text { Individuals who have } \\
\text { high incomes and KPR } \\
\text { are more likely to have } \\
\text { hajj savings. }\end{array}$ \\
\hline
\end{tabular}

Source: Authors' findings

\section{CONCLUSION AND RECOMMENDATIONS}

\subsection{Conclusion}

This study aimed to determine the factors that influence banking customerss ownership of financial assets. The information is intended to be used to map customer characteristics by Islamic banking in order to develop banking products that meet three levels of financial needs, namely basic needs (darruriyah), complementary needs (hajiyyah) and development needs (tahsiniyah).

The results indicate that the pattern of ownership of financial assets follows the order of the level of need based on the pyramid of Maslahah; financial products for transaction purposes are owned by almost all the respondents, those for precautionary purposes are owned by around 30\%, and products for investment are only owned by $10 \%$ of the respondents. There is an interesting pattern in which ownership of one financial asset is closely related to that of another. Securitybased financial asset ownership is also closely related to asset ownership for investment. Those who have one security-based financial asset product will tend to have another. Likewise, someone who has investment-based financial assets will certainly have other financial assets for transaction and precautionary needs.

Using logistic regression, it was found that financial asset ownership was influenced by several different factors. Ownership of financial assets for transaction needs is largely determined by the income variable, credit ownership and type of work, while ownership of financial assets for security or precautionary 
needs is largely determined by life cycle variables such as age and marital status. Ownership of financial assets for investment needs is strongly influenced by the level of education of the respondents and their economic welfare, while ownership of assets for special needs, namely that of pilgrimage, is more influenced by income levels and gender. The results of this research could be used for developing products and services in Islamic banking.

\subsection{Recommendations}

Several important findings were made related to factors influencing banking customer financial needs. These can be compiled into several recommendations and research implications, as discussed below. The first recommendation is related to the research result that there is a close correlation between security-based financial asset ownership and other security-based financial asset ownership , and also a close correlation between security-based financial assets and investmentbased ones. These findings could be used by banks to optimise their marketing strategies by using cross-selling and up-selling approaches. Cross-selling strategy is used to market similar products to existing customers. This study considers the tendency of consumers who already have security-based financial products such as deposits to have a greater interest in other security-based financial products, such as education savings and savings plans.

Moreover, Islamic banking could also use up-selling strategy to market products at a higher level, which in this case are marketing investment banking products to existing customers who use security-based financial products. Islamic banking has an opportunity to develop investment-based financial products that are currently needed by respondents.

There are several obstacles to investing through a Sharia bank, which are related to the lack of types of investment products and the lack of facilities offered by the banks. Islamic banks can respond by creating halal investment products to meet the financial needs of customers at the embellishment level. For regulators, it is important to provide support in the form of regulations and incentives for Islamic banking to create new products, especially investment-based ones.

The study has several limitations, one of which is that the research has not been able to explain further the needs of the poor. Therefore, it is suggested that this issue be further explored, as according to the pyramid of Maslahah, one of the basic needs that must be met by Islamic banks is that for financial products and services for the poor.

\section{Acknowledgments}

This research was funded by the Department of Sharia Banking of the Indonesian Financial Services Authority under the Research Fellowship Program 2016. 


\section{REFERENCES}

Ahmed, H. (2011a). Maqasid al-Shari'ah and Islamic financial products: A framework for assessment. ISRA International Journal of Islamic Finance, 3(1), 149-160.

Ahmed, H. (2011b). Product development in Islamic banks. Glasgow: Edinburgh University Press.

Ameriks, J., Caplin, A., Laufer, S., \& Van Nieuwerburgh, S. (2011). The joy of giving or assisted living? Using strategic surveys to separate public care aversion from bequest motives. The Journal of Finance, 66(2), 519-561.

Aris, N. A., Othman, R., \& Azli, R. M. (2013). Pyramid of Maslahah for social and economic welfare: The case of Bank Islam Malaysia Berhad. Journal of Energy Technologies and Policy, 3(11), 457-470.

Bodie, Z., Treussard, J., \& Willen, P. (2007). The theory of life-cycle saving and investing. FRB of Boston Public Policy Discussion Paper, 07-3.

Cagetti, M. (2003). Wealth accumulation over the life cycle and precautionary savings. Journal of Business \& Economic Statistics, 21(3), 339-353.

Lansing, J. B., \& Morgan, J. N. (1955). Consumer finances over the life cycle. Consumer Behavior, 2(4), 36-50.

Longobardi, S., \& Pagliuca, M. M. (2016). Determinants of Italian households' financial asset holdings: Some empirical evidence. International Journal of Research in Business Studies and Management, 3(11), 50-56.

Modigliani, F., \& Brumberg, R. (1954). Utility analysis and the consumption function: An interpretation of cross-section data. Franco Modigliani, 1(1), 388436.

Peijnenburg, K. (2018). Life-cycle asset allocation with ambiguity aversion and learning. Journal of Financial and Quantitative Analysis, 53(5), 1963-1994.

Poterba, J. M., \& Samwick, A. A. (1997). Household portfolio allocation over the life cycle. NBER Working Paper No, 6185.

Qiu, J. (2016). Precautionary saving and health insurance: A portfolio choice perspective. Frontiers of Economics in China, 11(2), 232-264.

Shefrin, H. M., \& Thaler, R. H. (1988). The behavioral lifecycle hypothesis. Economic Inquiry, 26(4), 609-643.

Sung, J., \& Hanna, S. D. (1996). Factors related to risk tolerance. Financial Counseling and Planning, 7, 11-19.

Xiao, J. J. (1996). Effects of family income and life cycle stages on financial asset ownership. Journal of Financial Counseling and Planning, 7, 21-30.

Xiao, J. J., \& Anderson, J. G. (1997). Hierarchical financial needs reflected by household financial asset shares. Journal of Family and Economic Issues, 18(4), 333-355. 
This page is intentionally left blank 